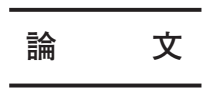

\title{
市町村合併を契機とした入会林野の展開に関する一考察 一岩手県一関市大東町旧鳥海村地区の共有林を事例として一
}

\author{
佐々木一也 ${ }^{*, 1}$ ・岡田秀二 ${ }^{2}$
}

\begin{abstract}
市町村合併と共有林との関わりおよび共有林の展望・課題を明らかにする立場から, 一関市大東町の旧鳥海村地区を事例と して取り上げ, 以前と現在の共有林の状況を概観し, 市町村合併に伴う展開の整理を行った。調査は, 聞き取り調査, アン ケート調査および資料・文献調査によって行った。結果として,（1）かつて入会慣行が存在した共有林も経営的には低調で あったこと，(2) 市町村合併に伴って 186 ha の林野が正式に地元地区の所有となったことを機に, 地区内の共有林の管理運 営組織を一元化する方向付けがなされたこと，（3）（2）について地元住民の理解度は高く, 地域自ら林野の支え手となる意識 がある一方，他の主体との関わりを受け入れる意識が低く，また森林の公益的機能発揮に対する期待が高いこと等が明らかに なった。共有林という地域資源の有効活用を図る上で, 森林のもつ多面的な機能に注目し，他の主体との連携も視野に入れた 幅広い視点からの利活用策の検討が重要な課題となろう。

キーワード : 入会林野, 共有林, 市町村合併, 集落, 生産森林組合
\end{abstract}

\begin{abstract}
Kazuya Sasaki ${ }^{*, 1}$ and Shuji Okada ${ }^{2}$ (2009) A Discussion of Common Forest Developments, Which Was Caused by Municipal Mergers: A Case Study of the Forest under Common Ownership in the Former Toriumi District. J. Jpn. For. Soc. 91: 71-78. The forest under common ownership in the former Toriumi district (now in Daito, City of Ichinoseki, Iwate Prefecture) provides a case study to clarify the relationship between municipal mergers and forests under common ownership in terms of management vision and issues for the future. First, the former and current state of this forest is reviewed, followed by information on developments accompanying municipal mergers in the area. The study consisted of interviews, a questionnaire survey, and document and literature searches. Results revealed that: (1) management of the forest was slack despite common ownership practices in the past. (2) Upon a forest of 186 ha belonged to the district formally with municipal mergers, relevant parties agreed to merge management and operation of the district's forests. (3) The local population agreed to this move and was aware of the region's responsibility for its own forests but had limited awareness of the need for relationships with other bodies. And they expect a forest function of public benefit. Focusing on the varied roles of forests and studying usage policies intended a tie-up with other bodies are crucial issues that are intended to effectively utilize local resources like forests under common ownership.
\end{abstract}

Key words: common forest, forest under common ownership, municipal merger, production forest association, village

\section{I. はじめに（研究の背景と目的）}

かつて共同的に利用・管理されてきた林野に目を向ける と，長きにわたる林業の低迷も背景に，森元ら（2006）が 指摘するように，林野の活用に対する期待は低く，関係者 以外の人々はもとより地元地域の住民の間ですら関心が薄 れつつさえある。そのような中で, 平成の市町村合併が大々 的に進められた。全国の市町村数は, 平成の市町村合併で 約 3,200 から約 1,800 へと $44 \%$ もの減少をみせており, 岩手 県内の市町村数も 58 から 35 に大きく減少 $(-40 \%)$ した (表-1)。「目的は各時代によって異なるとはいえども, 公的 部門が半ば強行に合併を推進し，そしてその裏側で旧村財 産が公的・私的な部門へ分解されていくという展開は, 明 治・昭和・そして今次の合併でもほとんど変わらない構図 である」（三俣, 2006）とされるように, 市町村合併は地域 の林野に大きな影響を与えてきた。今次の合併でも多くの 地域で地域資源である林野を今後どのような形で残してい
くかという課題に直面することとなった。

共同的な利用・管理に供される林野のひとつとして入会 林野が挙げられる。それは後に入会林野整備によって生産 森林組合を設立したものや，過去の市町村合併を経て財産 区有林や市町村有林等に姿を変えてきたものも多く，その いずれもが，それぞれ設立過程や歴史的経緯において地域 的な特色を有している。生産森林組合有林や財产区有林, 市町村有林となったものが一定の管理運営体制下に置かれ ている一方, 同じく実質的入会林野で現在まで共有林（本 稿では,「複数の個人や会社などが共同で所有する林野」と いう一般的な定義づけをして「共有林」と表記する), とり わけ記名共有の形を取り続けてきた林野は, 一般的に運営 組織が脆弱といえる。そのような林野に, 今回の市町村合 併はいかなる影響を与えているのであろうか。

市町村合併と入会林野との関わりの視点から, 矢野 （2006a）は，「明治の大合併時には市制・町村制の中に財産 区制度と旧慣使用権という制度が，また昭和の大合併時に

* 連絡先著者 (Corresponding author) E-mail: kzyasski@iwate-u.ac.jp

1 岩手大学大学院連合農学研究科 T 020-0581 岩手県岩手郡零石町御明神大石野 (The United Graduate School of Agricultural Science, Iwate University, Oishino, Omyojin, Shizukuishi, Iwate 020-0581, Japan)

2 岩手大学農学部共生環境課程 † 020-8550 盛岡市上田 3-18-8 (Environmental Sciences for Sustainability, Faculty of Agriculture, Iwate University, 3-18-8 Ueda, Morioka 020-8550, Japan)

(2008 年 3 月 25 日受付 ; 2008 年 10 月 14 日受理) 
表-1. これまでの市町村合併の概要と入会林野との関わり

\begin{tabular}{|c|c|c|c|}
\hline & 明治の町村合併 & 昭和の市町村合併 & 平成の市町村合併 \\
\hline 年 代 & $1888 \sim 1889$ & $1953 \sim 1961$ & $2002 \sim 2008.3$ \\
\hline 契 機 & 市制・町村制の施行 & 法の施行 & 地方分権改革？ \\
\hline 市町村数 全国 & $71314 \rightarrow 15859$ & $9868 \rightarrow 3472$ & $3218 \rightarrow 1821$ \\
\hline の変化 岩手県 & $642 \rightarrow 241$ & $221 \rightarrow 63$ & $58 \rightarrow 35$ \\
\hline 性 質 & 強制的 & 半ば強制的 & 任意的 \\
\hline 対共同体の方針 & 部落割拠の打破 & - 町内会の否定 & $\begin{array}{c}\text { 放置・放任? } \\
\text { 切り捨て? }\end{array}$ \\
\hline $\begin{array}{c}\text { 入会林野への } \\
\text { 措置 }\end{array}$ & $\begin{array}{c}\text { 財産区 (114 条) } \\
\text { 昍慣使用榷 (83 条) }\end{array}$ & $\begin{array}{c}\text { 新財産区 (294 条) } \\
\text { 財産区管理会 }(296 \text { 条の } 2) \\
\text { 旧慣使用権 (209 条) }\end{array}$ & 新たす \\
\hline
\end{tabular}

矢野達雄「市町村合併と入会林野」(2006b) から引用。一部, 筆者加工。 「入会林野への措置」欄の（）は, 明治の町村合併については市制・町村 制，昭和の市町村合併については地方自治法の条項である。

は（いわゆる）新財産区制度がそれぞれ設けられたが，今回 の合併に関しては林野を想定した新たな制度が用意されて いない」と整理した（表-1）。そしてそれは, 「前 2 回と比 し，林野の経済的重要性が低下したという事情を反映して」 いると分析している。そのような中で,「所有形態において も利用実態においても，地域の入会林野に大きな変容を迫っ た市町村合併史」（三俣，2006）にも焦点を当てながら，今 次の市町村合併に際して入会林野に起こっている問題を明 らかにしょうとした三俣（2006）の論考などは示唆に富む。 同様の問題意識から，地域の状況を把握・整理するとともに 今後の動向を注視していくことは重要といえよう。

ほかにも入会林野に関する研究に目を向けると, 入会林 野全体を捉えては，古くに数多くの研究が報告されたあと 入会林野整備の動向に合わせるように低調になった時期を 経て，再び報告がみられるようになってきたことを岡田ら （2006）が整理している。また，財産区有林についても，近 年になって事例整理や報告がみられるようになってきた （たとえば，三俣，2001，2004；室田ら，2004；斎藤ら， 2007)。さらに最近では, 林野の共同的な利用・管理に注目 した報告が多く行われるようになってきている（たとえば, 山下, 2006, 2007 ; 岩本, 2007 ; 伊藤, 2007)。しかしなが ら，共有林に焦点をあてた報告例は少なく，各地にある共 有林の実態を明らかにする上では十分ではない。

筆者らは森林のもつ多面的機能の発揮や地域の機能維持 の観点から, 共有林の実態と, 山村の地域や集落で自らが 関係する林野を住民がどのように意識し今後の取扱をどの ように考えるのか，に注目している。本稿では，岩手県旧 大東町（現一関市）の旧鳥海村地区を事例として取り上げ, 以前と現在の共有林の展開を整理し, 平成の市町村合併に 係る動きを捉えた上で，市町村合併と共有林との関わり， 今後の共有林管理の展望・課題を明らかにすることを目的 とした。

\section{II. 調査地および調查方法}

旧大東町は平成 17 年 9 月に 1 市 3 町 2 村と合併し, 新た な一関市となった。林野面積約 $200 \mathrm{~km}^{2}$ (林野率 $71.9 \%$ ), 人 口 16,704 人 (平成 17 年国勢調査) の山村で, 岩手県南部,
北上山地の南端に位置している。基幹産業は農林業で, 農・ 畜・林の複合経営が拈もな形態となっている。林野につい てみると, 国有林の割合が $5 \%$ ときわめて低く, また人工林 率 $(55 \%)$ ) が県平均 (43\%) を上回って高いことが特徴で ある。

この旧大東町内のかつての旧村である鳥海村地区の共有 林等を調查対象とした。岩手県内における整備着手入会林 野（8,612 ha）を旧市町村別にみた場合に, 旧大東町が面積 で 4 位 $(640 \mathrm{ha})$, 割合で $7.4 \%$ を占めており, そのうち約 6 割（382 ha）が旧鳥海村地区にあることがその理由である。 なお, 旧鳥海村地区の共有林等も整備着手入会林野に位置 づけられている（岡田ら，2004）。

調查は, 旧大東町および共有林組合等への聞き取り調查, 旧鳥海村地区を対象に行ったアンケート調查ならびに資 料・文献調査によって行った。

\section{III. 結果}

\section{1. 旧大東町時代の共有林の概要}

旧大東町の共有林について, 昭和 47 年の大東町総合調査 報告書は,「明らかに入会的利用の実質を持つと思われる集 団」（15 集団）を取り上げながら，綿密な調査結果を報告し ている。本調查は, 当時町の新しいビジョン策定を視野に 当時の現状をまとめることを目的に, 町の委託調査として 行われたものである（調查期間昭和 44 年 7 月〜 46 年 11 月 ; 分担者船越)。

報告書によると，第 1 に，表-2 の「成立闌」にあるよう に, 共有林の成立は多くが旧村有林や国からの払下げに よっている。そこには入会慣行が根強く存在しており, 入 会権の整理を図る上で, 共有林への移行が選択されたこと を物語っている。

第 2 に, 組織の運営にあたり規約をもつ集団は約半数に とどまり, 運営方針等についても権利者の寄合によって決 するものがほとんどである。いき抏い，経営計画を編成し， かつ実行しているケースは 15 集団のうち 3 集団にとど まっている（表-2中「運営」および「経営計画」欄）。

第 3 に，共有林成立後，「(権利者のもつ権利は）共有権 であり, 持分の売買譲渡は法的には可能であるから部落外 流出を防止することはできず, 多数集団の共有林では, そ の傾向が最近特に強まっている。」(括弧内筆者) と分析し ている。権利の取得に総会承認を必要としたり, 部落内者・ 権利者間での売買・譲渡が奨励されたりしているが（表-2 中「権利の取得」および「転出者の権利」闌), 共有形態で ある以上，十分な規制がはたらいてきたともいえないであ ろう。また，権利の相続によって細分化された権利の発生 も当然に考えられ，このことは共有林経営の意思決定に影 響を与える一つの要因であったであろう。

第 4 に, 当時の労務事情は, 権利者の無償出役と, 作業 量が多い場合の非出役権利者に対する出不足金の徵収とが 大勢であった（表-2 中「労務」欄）。しかし, 報告書が「本 格的な経営未だしの本町共有林にあって, 経営のための労 
表-2. 旧大東町内の共有林調査結果の概要（大東町総合調査（S44～46）の調査結果から）

\begin{tabular}{|c|c|c|c|c|c|c|c|c|c|c|c|c|c|c|c|c|c|c|c|c|c|c|}
\hline & & & & 成立 & & & 運営 & 経営 & 計面 & & & & & 権利関係 & & & 労 & 務 & & 経営 & 意思 至 & \\
\hline & $\begin{array}{l}\text { 名 } \\
\text { 義 } \\
\text { 数 }\end{array}$ & $\begin{array}{l}\text { 面 } \\
\text { 積 } \\
\text { 調 } \\
\text { 查 } \\
\text { 値 }\end{array}$ & $\begin{array}{l}\text { 時 } \\
\text { 期 }\end{array}$ & $\begin{array}{l}\text { 起 } \\
\text { 睲 }\end{array}$ & $\begin{array}{l}\text { 納 } \\
\text { 帨 } \\
\text { 財 } \\
\text { 源 }\end{array}$ & 替 & $\begin{array}{l}\text { 意 } \\
\text { 決 } \\
\text { 定 }\end{array}$ & \begin{tabular}{|l|} 
編 \\
成
\end{tabular} & 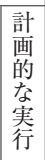 & 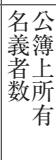 & $\begin{array}{l}j \\
5 \\
\text { 部 } \\
\text { 落 } \\
\text { 内 }\end{array}$ & \begin{tabular}{|l|} 
権 \\
悡 \\
$\infty$ \\
総 \\
数 \\
\end{tabular} & $\begin{array}{l}\text { 権所 } \\
\text { 者有 } \\
\text { の者 } \\
\text { 至 } \\
\text { 致角 } \\
\text { 益 }\end{array}$ & $\begin{array}{l}\text { 権 } \\
\text { 犁 } \\
の \\
\text { 取 } \\
\text { 得 }\end{array}$ & $\begin{array}{l}\text { 転 } \\
\text { 著 } \\
0 \\
\text { 権 } \\
\text { 利 }\end{array}$ & $\begin{array}{l}\text { 権 } \\
\text { 梨 } \\
\text { 者 } \\
\text { 出 } \\
\text { 役 }\end{array}$ & $\begin{array}{l}\text { 有 } \\
\text { 償 }\end{array}$ & \begin{tabular}{|l|} 
無 \\
償
\end{tabular} & \begin{tabular}{|l} 
出 \\
橾 \\
徵 \\
双
\end{tabular} & & & \\
\hline A & 70 & 99.04 & S15 & 村有林払下げ & 合費徵収 & 0 & 設置組織 & 0 & 0 & 70 & 70 & 72 & 一致 & $\begin{array}{l}\text { 譲渡 } / \\
\text { 総会承認 }\end{array}$ & 権利者への譲沙 & ○ & & & 0 & O & & \\
\hline B & 31 & 15.00 & S4 & 合併に伴う特売 & 自の所得 & $x$ & 置組織 & 0 & 0 & 31 & 23 & 31 & 不一致 & 部落内譲渡 & 岶に売 & $\mathrm{O}$ & & 0 & & $\bar{c}$ & 5 & \\
\hline $\mathrm{C}$ & 27 & 10.50 & S29 & 村有林払下げ & 各自の所得 & $\times$ & 権利者寄合 & $x$ & $x$ & 27 & 27 & 27 & 不一致 & $\begin{array}{l}\text { 部落内譲渡／ } \\
\text { 総会承認 }\end{array}$ & 部落内者に売る必要 & o & & & 0 & C & D & \\
\hline $\mathrm{D}$ & 8 & 1.50 & 54 & 有林払下げ & 所得 & - & 利者寄合 & $x$ & $x$ & 8 & 0 & 8 & 一致 & - & - & O & & $O$ & & $-{ }_{-}-$ & - & \\
\hline $\mathrm{E}$ & 74 & .00 & 33 & 有林払下げ & 売払い & $\mathrm{O}$ & 利者寄合 & $x$ & $x$ & 74 & 67 & 74 & 一致 & 譲渡 & 不変 (権利残) & - & - & - & - & O & & \\
\hline $\mathrm{F}$ & 101 & 105.00 & T12 & $\begin{array}{l}\text { 村有林購入 (部落 } \\
\text { 有林野統一事業) }\end{array}$ & 立木処分 & 0 & 権利者寄合 & $x$ & $x$ & 101 & 99 & 101 & 一致 & \begin{tabular}{|l} 
譲渡 $/$ \\
総会承認
\end{tabular} & $\begin{array}{l}\text { 不変 (権利残), 権利者 } \\
\text { への䜊渡を奨励 }\end{array}$ & o & & & 0 & 0 & & \\
\hline G & 9 & 7.95 & S23 & & $\begin{array}{l}\text { 権利者から } \\
\text { 徵収 }\end{array}$ & - & 権利者寄合 & 0 & $x$ & 9 & 9 & 9 & (一致) & 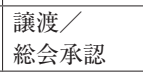 & $\begin{array}{l}\text { 不変 (権利残), 権利者 } \\
\text { への譲渡を奨励 }\end{array}$ & 0 & & 0 & & ○ & & \\
\hline $\mathrm{H}$ & 33 & 20.39 & M12 & 入会山を登録 & 薪木の代金 & 0 & 権利者寄合 & 0 & 0 & 33 & 30 & 33 & 一致 & \begin{tabular}{|l} 
総会承認 / \\
部落内者
\end{tabular} & $\begin{array}{l}\text { 権利者への譲渡が必要, } \\
\text { 不変 (権利残) }\end{array}$ & 0 & & & 0 & 0 & & \\
\hline I & 22 & 120.00 & M1 & & 各自の所得 & 0 & 権利者寄合 & $x$ & 0 & 22 & 21 & 22 & 不一致 & $\begin{array}{l}\text { 譲渡 } / \\
\text { 総会承認 }\end{array}$ & \begin{tabular}{|l} 
不変 (権利残), \\
部落外者へ譲渡も可, \\
権利者への棓渡を奖励
\end{tabular} & - & - & - & - & 0 & & \\
\hline $\mathrm{J}$ & 21 & 326.22 & M26 & $\begin{array}{l}\text { 部落有林野の } \\
\text { 買い戻し }\end{array}$ & 雑木売払い & 0 & 権利者寄合 & $x$ & $x$ & 21 & 18 & 21 & 一致 & \begin{tabular}{|l} 
譲渡・ \\
全権利者承認
\end{tabular} & $\begin{array}{l}\text { 不変 (権利残), 権利者 } \\
\text { 部落内者への譲渡を奨励 }\end{array}$ & O & & 0 & & c & o & \\
\hline $\mathrm{K}$ & 4 & 41.67 & ? & 町有林払下げ & 伐等収入 & - & 権利者寄合 & $x$ & 0 & 4 & $\Delta$ & 4 & 一致 & - & 不変（権利残） & - & - & - & - & C & b & \\
\hline $\mathrm{L}$ & 42 & 38.50 & M37 & 国から払下げ & 共有者均等割 & - & 権利者寄合 & $x$ & $x$ & 21 & 18 & & 一致 & 譲渡 & 不変（権利残） & 0 & & O & & C & b & \\
\hline $\mathrm{M}$ & 20 & 1.20 & M37 & 国から払下げ & 共有者均等割 & - & 権利者寄合 & $x$ & $x$ & 20 & 18 & & 一致 & 譲渡 & 不変（権利残） & - & - & - & - & 0 & & \\
\hline $\mathrm{N}$ & 20 & 1.80 & M37 & 国から払下げ & 共有者均等割 & 0 & 設置組織 & 0 & $x$ & 20 & 19 & & 一致 & 譲渡 & 不変 (権利残) & O & & O & & 0 & & \\
\hline $\mathrm{O}$ & 20 & 1.70 & M37 & 国から払下げ & 共有者均等割 & 0 & 設置組織 & 0 & $x$ & 20 & 18 & & 一致 & 譲渡 & 不変 (権利残) & 0 & & $\mathrm{O}$ & & 0 & & \\
\hline
\end{tabular}

大東町（1972）大東町総合調査報告書 370 381ページの表 4-2 を筆者が加工して作成。

働力問題はそれほどシビアではない。とするように, 労務 問題は共有林経営において重要課題ではなかった。

第 5 に，経棠意思をみてみると，5集団が「改善したい」 と回答している (表-2 中「経営意思」欄)。中には, 当時既 に生産森林組合に改組した共有林組合もある。反対に, 現 状是認のスタンスの共有林組合は林業経営意欲も低調で あっただろうし，負担を受け入れてまで造林を行う意欲が なかったものと思われる。この部分に関し報告書は,「低調 な経営意欲とそれとうらはらな権利関係の複雑さの解決の ためには, 恐らく長い年月を要することであろう。」と指摘 している。

\section{2. 現在の旧鳥海村地区の共有林および市町村合併に伴 う動き}

ここでは, 旧大東町農林課職員, 各共有林組合長および 鳥海生産森林組合事務局長（前大東町職員）に対して行っ た聞き取り調查の結果から明らかになった点を整理する。

現在, 旧鳥海村地区には, 次に掲げる一つの生産森林組 合と三つの共有林組合がある（図-1 および表-3）。i ）鳥海 生産森林組合 (組合員 228 名/面積 291 ha ; 数值は H18 末現 在。以下同。，，ii）鳥舘共有林組合（組合員 73 名/面積 61 ha), iii）丑石共有林組合（組合員 101 名/面積 $97 \mathrm{ha}$ ), iv）市之通共有林組合（組合員 34 名/面積 39 ha）。これら はいずれも，かつての部落有林野統一政策により「形式市 町村有・実質部落有となったもの」（川島，1973）の払下げ を受けるなどにより成立したものである。図-2 はこれらの 組合員の関わり（組合員数）を示している。この図から，

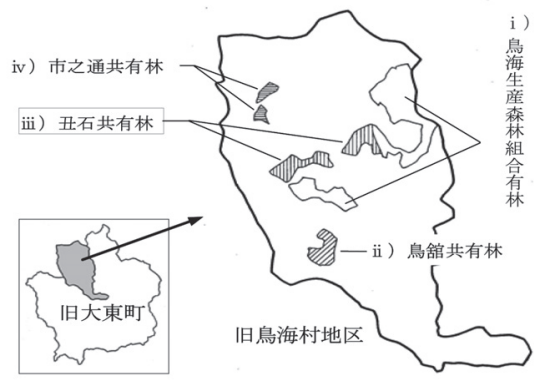

図-1. 旧大東町と旧鳥海村地区の共有林等

旧鳥海村地区全世帯（413）のうちいずれの組合員でもない 者が 185 名（世帯）いることがわかる。

i ）の鳥海生産森林組合は, 前身である前森生産森林組 合（S44 年設立/組合員 69 名（H17）/105 ha）を再編し，鳥 海早期育成林組合（S41 年設立/組合員 246 名/186 ha）を統 合して平成 17 年 7 月に設立された。前森生産森林組合と は, もともとは昭和 15 年に村からの払下げを受けて成立し た共有林組合が, 昭和 44 年にいわゆる近代化法による入会 林野整備によって生産森林組合となったもので, 72 名（の ちに 69 名）の記名共有で 105 ha の林野を所有していた。こ のうち約 8 割が県行造林となっており, 組合としての事業 活動は低位であり, 経営も苦しい状態が続いてきた。一方, 鳥海早期育成林組合とは，かつての部落有林野統一によっ て旧村の財産となり,のちの昭和 40 年代はじめに町からの 
表-3. 旧鳥海村地区の共有林組合の概要

\begin{tabular}{|c|c|c|c|}
\hline & 鳥舘共有林組合 & 丑石共有林組合 & 市之通共有林組合 \\
\hline 成立 & 村有林払下げ（S33） & 村有林購入（T12） & 村合併に伴う特売（S4） \\
\hline 面積 & 61 ha & 97 ha & 39 ha \\
\hline 組合員数 & 73 名 & 101 名 & 34 名 \\
\hline 規約の有無 & あり & あり & なし \\
\hline 役員の数 & 9 名 & 16 名 & 5 名 \\
\hline 総会の開催 & 臨時のみ & 3 年ごと & 案件あるとき（現在は毎年） \\
\hline 税納付 & すべて保安林のため非課税 & $\begin{array}{c}\text { 以前：組合費から } \\
\text { 現在：線下補償費から }\end{array}$ & 各自の所得から集金 \\
\hline 経営計画書 & なし & なし & なし \\
\hline 権利者以外の利用 & なし & なし & なし \\
\hline 転出者の権利 & 実質不変 & 実質不変 & 実質不変 \\
\hline 林野の状況 & $\begin{array}{l}\text { すべて県行造林 } \\
\text { (満期 H28.3) }\end{array}$ & $\begin{array}{l}\text { すべて町行造林 } \\
\text { （満期 H22.10） }\end{array}$ & （すべて雑木山） \\
\hline 10 年間の事業実績 & 実績なし & 実績なし & 実績なし \\
\hline 労務(出役)実績 & なし & $\begin{array}{c}\text { 境界刈払い } \\
\text { （森林整備地域活動支援交付金） }\end{array}$ & $\begin{array}{c}\text { 境界刏払い } \\
\text { （森林整備地域活動支援交付金） }\end{array}$ \\
\hline 組合費徵収 & $\begin{array}{c}\text { なし } \\
\text { (H18 分担金徴収 (1 万円/戸)) }\end{array}$ & なし & なし \\
\hline その他（備考） & $\begin{array}{l}\text { 所有権分割されている権利の整理が } \\
\text { 当面の課題。 }\end{array}$ & $\begin{array}{l}\text { 収入に結びつかないことを理由に，林野に } \\
\text { 対する期待低。いま，改めて林野の扱いを } \\
\text { どうするか，には関心大。 }\end{array}$ & 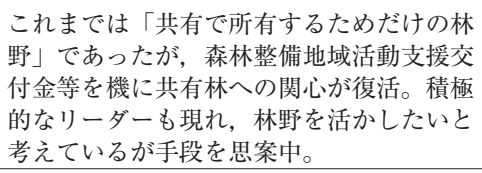 \\
\hline
\end{tabular}

聞き取り調查等から。数值は H18 末現在。

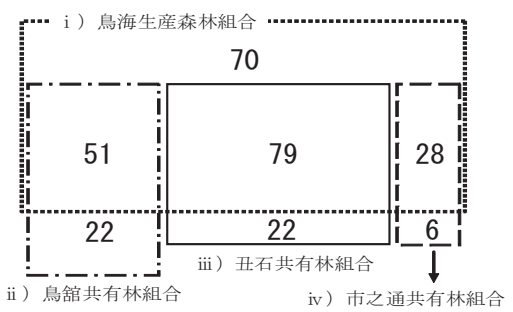

図-2. 旧鳥海村地区内各共有林組合等の組合員数

聞き取り調查をもとに作成。鳥海生产森林組合員以外の 50 名（世 帯）は町外在住者である。

無償払下げが決定した 186 ha の林野の管理を行うためにつ くられた任意の組合である。しかしながら当該林野は，こ れまで登記が行われないまま約 6 割を町行造林とし, 約 2 割が牧野として町に貸し付けられてきた。いわば「形式町 有実質入会」の形態を続けてきたことになる。

i ）～iv）のうち，iv）を除いて非常に多くの面積を対象 に分収林契約（県行造林，町行造林）が行われており，契 約以降は直営的な林野利用はほとんどみられない（大東町, 1972)。聞き取り調査からは，かつて家畜飼養のための採草 利用や薪炭材採取利用が，古典的共同利用や字を単位とす る割山利用的な形態をとって行われていたことが把握でき たが (図-3 参照), 昭和 40 年代から現在まで, 総じて粗放 な利用にとどまってきたのが実情である。表-3をみても， ここ10 年事業実績がないなど, 以前と比較して大きな変化 はないといえる。しかし，近年，二つの共有林組合で森林 整備地域活動支援交付金を活用した境界管理作業が行われ るなど，林野への関心の高まりがみられるようになった。 このことは，注目すべき点であると考えられる。

旧大東町の合併に当たり，これまで登記が行われずにき

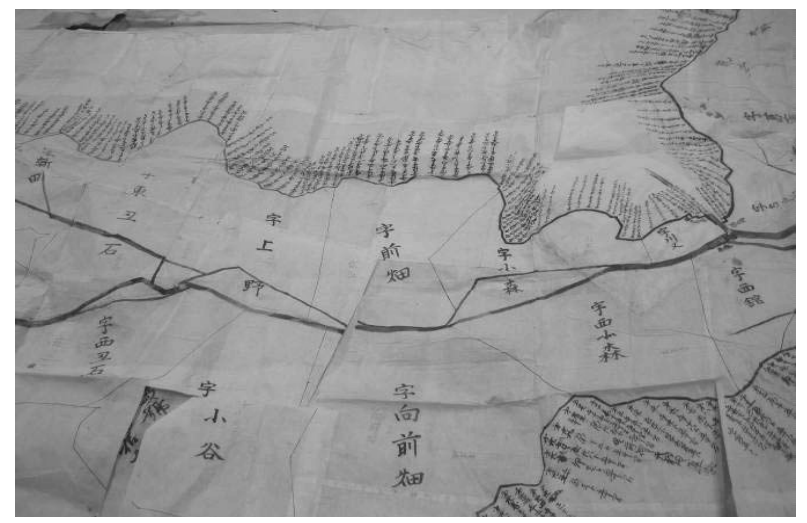

図-3．東磐井郡鳥海村繪圖

旧大東町沖田コミュニティセンターにて筆者撮影。縦に線が引か れ，利用区域が区分けされている。

た鳥海早期育成林組合の林野 (186 ha) の取扱が課題として クローズアップされた。これに対し，五つの組合の役員が 中心となり，旧鳥海村地区の共有林をより効率的に管理す ることを目的として運営組織を整理統合し，一つの生産森 林組合とする方向づけが行われた。整理統合後の形態を生 産森林組合とした背景については不明な点があり，断定的 なことはいえないが，既存の生産森林組合を含めての統合 である事情から，現行制度の中で生産森林組合への統合が 自然であると組合役員等関係者が判断したものと考えるこ とができる。具体的には，まず，前森生産森林組合と鳥海 早期育成林組合を統合・再編し，鳥海生産森林組合を設立 する。一方，三つの共有林組合を入会林野整備によって解 消した上で生産森林組合を設立し, 最終的にこれら二つの 生産森林組合を統合することが計画されたのである。入会 
林野整備によって生産森林組合を設立すれば，代位登記や 税制特例などの措置が適用される。しかし，過去に入会林 野整備を行って設立された前森生産森林組合を含む五つの 関係する組合を一度に一つの組織に統合する方法では，こ うした措置の対象にならない。関係者の負担軽減の視点が 大きな因子としてはたらいている。

この計画の実現に向けて, 前出の鳥海生産森林組合事務 局長が，五つの組合の意見集約をはじめ各戸への説明資料 の配付, 説明会の開催, 権利者への個別説明および権利者 の確定作業等に力を注いでいる。数百名の権利者が関わり 作業が繁雑さをきわめる中で，一定の方向性に理解を得て， 実際に事態を動かしていくためには，こうした強いリー ダーシップが不可欠であろう。また，町（行政）の協力も 欠かせない。全国の入会林野整備実績が件数・面積ともに ピーク時の $5 \%$ 未満となっている現在, ともすると入会林野 に対する市町村サイドの受け止めが弱くなりかねないが, 旧大東町は地元地域と県との調整等を積極的に行ってきて おり，こうした町（行政）の支援態勢は重要である。

\section{3. 地元地域の意識}

次に，地元地域の住民が，地域の森林や 2. で述べたよう な組織の統合・再編についてどのような考えをもっている かなどを主題として，旧鳥海村地区の全世帯（413 世帯）を 対象に行ったアンケート調査の結果から明らかになった要 点を整理する。なお, アンケート調査は, 平成 19 年 10 月 に留置き法により行った。回収率は $93.7 \%$ であったが，白 票が多かったことにより有効回答率は $63.2 \%$ にどまって いる。

（1）ここ 10 年間で林業収入実績があった世帯はごくわず か (4.1\%) であるが, 所有森林の手入れを 1 年以内に 1 回 程度行った割合をみると，森林所有者全体で $39.1 \%$ ，共有 林組合員では 47.4\%となっており，森林の維持管理が放棄 されてはいない（表-4）。（2）組合員であることのメリット として多かった回答が「組合員間のつながりを維持できた」 （26.5〜37.7\%）であり，また組合総会へは「どちらかとい えば参加していた」を含め「参加していた」が 53.3〜 57.9\% であるなど，共有林組合等は組合員間の関わりを維持し続 けさせるものとして機能してきた（表-5）。（3）地域の森林 に対する関心度についてみると，三つの共有林組合員拉よ び鳥海生産森林組合員（以下「組合員」という。）で約 4 分

表-4. 所有森林の手入れ状況

\begin{tabular}{lcccr}
\hline & $\begin{array}{c}\text { 森林所有者 } \\
\text { 全体 }\end{array}$ & $\begin{array}{c}\text { 共有林 } \\
\text { 組合員 }\end{array}$ & $\begin{array}{c}\text { 鳥海生産 } \\
\text { 森林組合員 }\end{array}$ & 非組合員 \\
\hline 半年以内に1 回程度 & $21(11.4)$ & $17(19.3)$ & $17(12.8)$ & $2(5.9)$ \\
1 年に1 回程度 & $51(27.7)$ & $37(28.1)$ & $40(30.1)$ & $9(26.5)$ \\
ほとんど手入れを & $105(57.1)$ & $74(52.6)$ & $73(54.9)$ & $20(58.8)$ \\
$\begin{array}{l}\text { そ行っていない } \\
\text { その他 }\end{array}$ & $7(3.8)$ & $4(0.0)$ & $3(2.3)$ & $3(8.8)$ \\
\hline
\end{tabular}

アンケート調查から。鳥舘，丑石，市之通の 3 共有林組合の組合員を 「共有林組合員」とし，共有林組合と生産森林組合のいずれにも属さない 者を「非組合員」とした（）は計に対するそれぞれの割合（\%)。共 有林と重複して鳥海生産森林組合の構成員となっている者がいるため, 計が森林所有者全体の数とは合致しない。
表-5. 組合員であること（あったこと）のメリットおよび総会 への参加状況

\begin{tabular}{|c|c|c|c|c|}
\hline & & 共有林組合 & $\begin{array}{l}\text { 鳥海早期 } \\
\text { 育成林組合 }\end{array}$ & $\begin{array}{l}\text { 前森生产 } \\
\text { 森林組合 }\end{array}$ \\
\hline & 林業収入を当てにできた & $23(17.4)$ & $6(4.9)$ & $5(5.5)$ \\
\hline & $\begin{array}{l}\text { 将来に向けて森林を安心して } \\
\text { 保持できた }\end{array}$ & $33(25.0)$ & $29(23.8)$ & $32(35.2)$ \\
\hline 省 & $\begin{array}{l}\text { 組合としてまとまりのある活 } \\
\text { 動ができた }\end{array}$ & $19(14.4)$ & $13(10.7)$ & $8(8.8)$ \\
\hline 卜 & $\begin{array}{l}\text { 組合員間のつながりを維持で } \\
\text { きた }\end{array}$ & $35(26.5)$ & $46(37.7)$ & $29(31.9)$ \\
\hline & その他 & $22(16.7)$ & $28(23.0)$ & $17(18.7)$ \\
\hline & 参加していた & $53(35.3)$ & $54(38.6)$ & $42(40.0)$ \\
\hline $\begin{array}{l}\text { 総 } \\
\text { 会 }\end{array}$ & $\begin{array}{l}\text { どちらかといえば参加して } \\
\text { いた }\end{array}$ & $27(18.0)$ & 27 (19.3) & $16(15.2)$ \\
\hline $\begin{array}{l}\text { 参 } \\
\text { 加 }\end{array}$ & $\begin{array}{l}\text { どちらかといえば参加して } \\
\text { いなかった }\end{array}$ & $26(17.3)$ & $20(14.3)$ & $18(17.1)$ \\
\hline & 参加していなかった & $44(29.3)$ & $39(27.9)$ & $29(27.6)$ \\
\hline
\end{tabular}

アンケート調查から。鳥舘, 丑石，市之通の 3 共有林組合をまとめて「共 有林組合」とした。（）は計に対するそれぞれの割合（\%)。また，有 効回答数が異なるため, 計は一致していない。

の 3 が関心があり関心度が高いものの, 非組合員では 54.8\%にとどまっている。しかしながら，地域の森林をどう にか維持発展させようとする体制整備（＝管理運営組織の 一元化 $=$ 一生産森林組合への統合）に対しては,「賛成であ る」とする回答率が一番低い非組合員でも $86.2 \%$ と, 組合 員非組合員を問わず多くが賛意を示し理解度が高い（表6 ：以下同)。(4) 地域の森林の今後の支え手について, 組 合員では「地元の地域住民」の回答が約 5 割を占め, 地域 自ら支え手となる意識がある一方，他の主体としては国・ 県・市の行政機関が約 4 割となっており, それ以外の主体 との関わりを受け入れる意識が低い。他方, 非組合員では 「地元の地域住民」が約 3 割, 「国・県・市」が約 5 割と, 組合員との間に違いがみられた。（5）地域の森林に期待す る機能として, 組合員で木材生産が根強くある（1 割強）も のの, 非組合員を含め総じていわゆる公益的な機能以外に 期待する機能の多様性が低い。（6）後継者事情を職業別に みてみると, 組合員については, 農家や自営業等では後継 者が決まっている割合が比較的高く (約 $5 \sim 7$ 割), 都市部 への人口流出が続く中で，いわゆる「家業」の継承がそれ なりに維持されている。他方, 非組合員ではこうした傾向 は認められず，様相が異なる。（7）現在住んでいるところ からの転出を望むものが $5.3 \sim 8.1 \%$ にどまるとともに, 集 落行事への参加率は一番低い非組合員でも $78.7 \%$, 組合員 では 9 割強と非常に高く, いまなお集落維持の意思がある と考えられる。

最後に, アンケート調查後に集計結果等を提示して改め て行った聞き取り調查（各組合の役員のうち 8 名を対象） において得られた補足すべき結果を挙げておく。

（1）最終的に統合されたあとの鳥海生産森林組合に対し, 組合員間の関わり, ひいては集落・地域内の関わりを築き 維持する機能をも期待している。（2）地域の森林を支える 新たな支え手については, 人と事業の継続性が維持できる かどうかがポイントとして考えられている。（3）比較的地 
表-6. アンケート調査結果集計表

\begin{tabular}{|c|c|c|c|c|c|c|c|}
\hline & & 共有才 & 木組合員 & 鳥海生产 & 森林組合員 & & 且合員 \\
\hline 地域の森林に & 関心がある & 111 & $(73.5)$ & 115 & $(75.2)$ & 40 & (54.8) \\
\hline 対する関心度 & 関心がない & 40 & $(26.5)$ & 38 & $(24.8)$ & 33 & $(45.2)$ \\
\hline 鳥海生産森林 & 知っている & 132 & (87.4) & 152 & (99.3) & 12 & (15.4) \\
\hline 組合の周知度 & 知らない & 19 & (12.6) & 1 & $(0.7)$ & 66 & (84.6) \\
\hline 組合統一に & 賛成である & 125 & $(89.3)$ & 132 & (91.0) & 50 & $(86.2)$ \\
\hline 対する賛否 & 賛成でない & 15 & (10.7) & 13 & $(9.0)$ & 8 & $(13.8)$ \\
\hline & 国 & 8 & (12.1) & 26 & (17.7) & 8 & (11.9) \\
\hline & 県 & 8 & (12.1) & 22 & $(15.0)$ & 14 & (20.9) \\
\hline & 市 & 9 & (13.6) & 15 & (10.2) & 12 & (17.9) \\
\hline & （小計） & & $<37.9>$ & & $<42.9>$ & & $<50.7>$ \\
\hline $\begin{array}{l}\text { 地域の秝林の } \\
\text { 今後の支え手 }\end{array}$ & $\begin{array}{l}\text { 地元地域の住民 } \\
\text { 都市住民 }\end{array}$ & 35 & $(53.0)$ & 71 & $(48.3)$ & 20 & (29.9) \\
\hline & 任意団体 & 5 & $(7.6)$ & 11 & $(7.5)$ & 6 & $(9.0)$ \\
\hline & 企業 & 1 & $(1.5)$ & 2 & $(1.4)$ & & \\
\hline & その他 & & & & & 7 & (10.4) \\
\hline & 災害防止 & 28 & (19.4) & 29 & (20.1) & 22 & (29.3) \\
\hline & 地球温暖化防止 & 31 & (21.5) & 28 & (19.4) & 19 & (25.3) \\
\hline & 水資源かん養 & 38 & (26.4) & 35 & (24.3) & 9 & (12.0) \\
\hline & 大気浄化 - 騒音緩和 & 0 & $(0.0)$ & & $(0.0)$ & 0 & $(0.0)$ \\
\hline & 保健休養の場 & 1 & $(0.7)$ & 2 & $(1.4)$ & 1 & $(1.3)$ \\
\hline 地域の森林に & 野生動植物生息の場 & 4 & $(2.8)$ & 5 & ( 3.5$)$ & 0 & $(0.0)$ \\
\hline 期待する機能 & 野外教育の場 & 4 & $(2.8)$ & 4 & $(2.8)$ & 1 & ( 1.3$)$ \\
\hline & 木材生産 & 16 & (11.1) & 20 & (13.9) & 5 & ( 6.7$)$ \\
\hline & きのこ等林産物生産 & 2 & $(1.4)$ & 3 & $(2.1)$ & 3 & $(4.0)$ \\
\hline & その他 & 2 & $(1.4)$ & 2 & $(1.4)$ & 2 & $(2.7)$ \\
\hline & 特にない & 6 & ( 4.2$)$ & 5 & ( 3.5$)$ & 6 & $(8.0)$ \\
\hline & わからない & 12 & $(8.3)$ & 11 & $(7.6)$ & 7 & ( 9.3$)$ \\
\hline & & 決まっている & 決まっていない & 決まっている & 決まっていない & 決まっている & 決まっていない \\
\hline & 専業農家 & $16(59.3)$ & $11(40.7)$ & $19(65.5)$ & $10(34.5)$ & $1(25.0)$ & $3(75.0)$ \\
\hline & 第一種兼業農家 & $12(63.2)$ & $7(36.8)$ & $15(68.2)$ & $7(31.8)$ & $2(50.0)$ & $2(50.0)$ \\
\hline & 第二種兼業農家 & $20(58.8)$ & $14(41.2)$ & $18(60.0)$ & $12(40.0)$ & $4(50.0)$ & $4(50.0)$ \\
\hline & 会社員 & $5(29.4)$ & $12(70.6)$ & $5(26.3)$ & $14(73.7)$ & $7(46.7)$ & $8(53.3)$ \\
\hline & 公務員 & $1(33.3)$ & $2(66.7)$ & $1(33.3)$ & $2(66.7)$ & & $1(100.0)$ \\
\hline 職業別 & 経営者（管理職・役員） & & & & & $2(50.0)$ & $2(50.0)$ \\
\hline 後継者事情 & 商工自営業 & $2(66.7)$ & $1(33.3)$ & $1(50.0)$ & $1(50.0)$ & $5(55.6)$ & $4(44.4)$ \\
\hline & 自由業 & $3(100.0)$ & & $4(100.0)$ & & $1(16.7)$ & $5(83.3)$ \\
\hline & パート, アルバイト & & $1(100.0)$ & & & & \\
\hline & その他 & $2(28.6)$ & $5(71.4)$ & $3(42.9)$ & $4(57.1)$ & $1(100.0)$ & \\
\hline & 無職 & $12(44.4)$ & $15(55.6)$ & $12(46.2)$ & $14(53.8)$ & $5(25.0)$ & $15(75.0)$ \\
\hline 定住意思 & $\begin{array}{l}\text { できるだけ現在住んでいる } \\
\text { 集落で暮らしたい }\end{array}$ & 137 & (91.9) & 140 & $(92.7)$ & 72 & $(94.7)$ \\
\hline & できればよそに移りたい & 12 & $(8.1)$ & 11 & $(7.3)$ & 4 & $(5.3)$ \\
\hline & 参加している & 81 & $(54.4)$ & 83 & $(55.0)$ & 29 & $(38.7)$ \\
\hline 集落行事 & どちらかといえば参加している & 54 & $(36.2)$ & 55 & $(36.4)$ & 30 & $(40.0)$ \\
\hline への参加 & どちらかといえば参加していない & 11 & $(7.4)$ & 11 & $(7.3)$ & 13 & (17.3) \\
\hline & 参加していない & 3 & $(2.0)$ & 2 & $(1.3)$ & 3 & $(4.0)$ \\
\hline
\end{tabular}

アンケート調查から。鳥舘，丑石，市之通の 3 共有林組合の組合員を「共有林組合員」とし，共有林組合と生产森林組合のいずれにも属さない者を「非組 合員」とした。（）は列項目の計に対するそれぞれの割合（\%)，＜＞は国・県・市の割合の計。また，有効回答数が異なるため，各項目の計は一致 していない。

域の森林に多面的な機能を期待している組合（集落）では, 保健休養等の観点から広葉樹林（雑木林）の造成を重視す る視点がもたれている。（4）後継者の決定に関わって，「家 業」の継承というよりはむしろ「家」の継承が維持されて いると捉える方が妥当である。（5）季節ごとの祭事など， 集落行事を支えに地元地域に生きている人たちも多く, 集 落維持の意思はいまなお強く存在している。

\section{IV. 考}

前述のように，今回の市町村合併を契機として，旧鳥海 村地区では共有林の運営組織を整理統合し，地域の森林を
管理していくことが方向づけられた。同時に，三つの共有 林組合が抱えてきた問題，すなわち組合員の部落外への転 出やそれに関わる権利関係の複雑化等の問題解決を図ろう とする気運が高まり, これらについては入会林野整備を行 うことで地域の合意がほぼ得られている。

ここで権利者の確定が大きな問題となった。転出者の所 有権が分割登記されている例もみられ, 権利者の確定と権 利の整理にかかる手続き作業において非常に困難をきわめ ている。この整理作業は容易でないが, 今後地域の共有林 の舵取りを担う鳥海生産森林組合が中心となって, 現在, 関係者の相続系統図の作成作業を進めながら権利者の確定 
を急いでいる。

構想が現実になれば，約 500 ha に及ぶ林野を所有するこ とになる。聞き取り調査において四つの組合すべてから「所 有したあと現実的に利活用できるか否かが重要である」旨 の回答が寄せられるなど，所有者個々にも，ただ所有して いるだけではいけない，との意識は高まってきている。

部落有林野統一などで市町村有地になりながらも実質入 会権を残してきたような林野の今後の展開について，矢野 （2006a）は四つのケース予想—（1）新市町村の財産に移行, （2）財産区等を設立，（3）もとの権利者である地元地区（部 落）に還元または払下げ，(4)旧市町村有名義のまま放置一 をするとともに，市町村合併と入会林野の関係を考える上 で考慮すべきポイントとして,「本来の権利者の権利が確保 されるか否か」「林野の持続的管理が行われるかどうか」の 2 点を挙げている。今回取り上げた組合のうち鳥海早期育成 林組合は，広義でケース（3）に該当する。また，他の三つ の共有林組合も市町村合併を契機とした展開の中で権利関 係の整理が図られ，新たな管理運営組織への移行が予定さ れているという意味では，矢野が挙げた二つのポイントが あてはまるであろう。

矢野による四つの予想ケースのいずれにおいても，たた ちに森林管理・林野利用の活性化につながるとは考えにく い。しかし，ケース（1）（3）については，権利関係の整 理とその結果として林野の持続的管理の態勢づくりが進む といえ，そのことは利点といえる。そして現実の地域に目 を向けたとき，筆者らは聞き取り調査等を通じ，矢野が挙 げた 2 点に必要な要素として「地元地区（部落）住民に相 応の意識があるかどうか」「地元行政機関の支援態勢が十分 か」「地元地区（部落）内でのリーダー（中心的人物）が存 在するかどうか」が重要であると考える。

今回の調查では，これまでどちらかというと林野と深い 関わりを持たずにきた地元地区（部落）住民が，III. 3.でみ たように，＜自分たちに関わりがある林野を今後どのよう にしていくべきか＞という点について，必ずしも全員が同 水準でないにしろ，これまでにはなかったほど関心を高く もち，自らが支え手となって地域の森林（林野）を維持管 理していく意識をもっていること，また，そのために重要 といえる集落維持の意思があることがわかった。そして旧 組織を統合・再編して新たな生産森林組合を設立させるな ど具体的に展開し始めている。入会林野整備の受け皿を生 産森林組合とすることの是非については議論の余地がある が，管理体制（組織）を整えて地域の林野を取り扱ってい こうとする前向きな姿勢は評価してよいと考える。

しかしながら，今後の展開を見通す上での課題も残され ている。運営組織の統一化が方向づけられ，関係者の合意 も得られていながら, 2 年以上が経過した現在も権利関係の 整理が終わらずに残る三つの共有林組合の入会林野整備が 進まないなど，次の展開に至っていない。身近な森林の維 持管理に対する意識を住民がもっている地域でさえこうし た状況にあるところに，林野の共同的管理を進める上での
大きな課題がみえる。

旧鳥海村地区の共有林は，総じて粗放な利用にとどまっ てきた。多くを官行造林としてきたことも関係し，必ずし も組合員と林野との関わりが深かったといえない。しかし, その官行造林もまもなく満期を迎えつつある。そして今回 の市町村合併を契機とする動きが，組合員に意識をもたせ， さらに地元住民にも関心をもたせたことは事実である。こ のあと所有することが予定される林野をどのように扱って いくか，その具体的な検討が今後旧鳥海村地区に課せられ る課題となる。三俣（2006）が指摘しているように，「市町 村合併の議論の中に，旧村有財産をめぐる地域自治力ある いは地域環境の保全という視点を組み入れるということも また必要」となろう。以前からの慣行を背景に, 林野の利 活用に対する意識が林産物販売収入に対する期待等に矮小 化されているとすれば，共有林の新たな利用展開を期待し にくいと考える。

アンケート調查結果からは, 森林に期待する機能として 公益的機能への偏りが窥われた。しかし見方を変えれば, 公益的機能に対する関心がそれだけ高いということでもあ る。今回取り上げた共有林組合の中にも, 森林がもつ保健 休養の機能にも着目しながら共有林野の利活用策を模索す る動きがみられるものもあり，こうした視点が重要である と考える。

他方, 支え手については，多様な主体との連携を視野に 入れた体制づくりの検討も求められよう。たとえば，全国 で森林づくりにかかわる活動を実施しているボランティア 団体の数は平成 18 年で 1,863 団体となり, 平成 12 年の 3.2 倍と近年大幅に増加している（林野庁，2008）。また，内閣 府が実施した「森林と生活に関する世論調査」によると， 森林を手入れするためのボランティア活動に $55 \%$ （前回調 査值約 $41 \%$ ）の者が参加の意向を示している。さらに，林 野庁の調查によると, 森林ボランティア活動に取り組む団 体の扮もな目的として一番多いのは「里山林等身近な森林 の整備・保全」であり, $67 \%$ の回答率（複数回答）となっ ている（林野庁，2007）。こうした背景を活かすような幅広 い視点からの検討が重要な課題になると考えられる。

旧鳥海村地区の共有林が一生産森林組合に統合された 後，実際にどのような管理運営が行われていくのか，また その上で課題となるものは何なのか，そして地元地区（部 落）の住民はそのことにどう対処していくのか。これらの 調查・分析を通じて, これらからの共有林のあり方に関す る考察を進めることが今後の課題である。

\section{引用文献}

大東町（1972）大東町総合調查報告書. 300pp, 大東町.

伊藤勝久 (2007) 中山間地域における資源管理とソーシャル・キャピ タルの存在状況一島根県雲南市を事例に一. http://wwwsoc.nii. ac.jp/jfes/kenkyukai/abstract/T2-4. pdf,2008.3.5

岩本純一(2007)滋賀県湖東地域における入会林野利用の展開. http:// wwwsoc.nii.ac.jp/jfes/kenkyukai/abstract/B-7.pdf, 2008.3.5

川島武宜編（1973）社会と法 1. 法社会学講座 7.432pp, 岩波書店, 東京. 
三俣 学 (2001) コモンズ論から見た財産区制度の環境保全的意義一 滋賀県甲賀郡甲賀町大原財産区有林を事例として. 林業経済研究 $47(3): 41-48$.

三俣 学 (2004) 財産区有林の管理害態に関する環境経済学的考察— 岩手県江刺市・滋賀県甲賀町の財産区有林を事例として. 京都精 華大学紀要 $27: 109-128$.

三俣 学 (2006) 市町村合併と旧村財産に関する一考察一環境保全・ コミュニティ再考の時代の市町村合併の議論に向けて一. 日本民 俗学 $245: 68-98$.

森元早苗・嶋田大作・田村典江・三俣 学・室田 武 (2006) 利用・ 管理形態の違いにみる森林管理に対する意識の比較一京都市右 京区山国地区での私有林と共有林を事例として一. 環境経済・政 策学会 2006 年大会報告要旨集 : 93-94.

室田 武・三俣 学 (2004) 入会林野とコモンズ一持続可能な共有の 森. $265 \mathrm{pp}$, 日本評論社, 東京.

岡田秀二・赤澤由明・永坂 崇 (2004) 入会林野整備と残存する入会 林野一岩手県のアンケート調査から一. 入会・コモンズ 2004： $39-48$.
岡田秀二・佐々木一也 (2006) 第 4 章 入会林野論.（林業経済研究 の論点一 50 年の歩みから一. 林業経済学会編, 日本林業調査会, 東京). 173-204.

林野庁（2007）森林づくり活動についてのアンケート集計結果：7.

林野庁（2008）平成 19 年度森林及び林業の動向：79.

斎藤暖生・山下詠子・浅井美香・泉 留維 (2007) 地域による共同的 な林野管理制度としての財産区一 2007 年悉皆調査による設置 現況と平成の市町村合併の影響—. http://wwwsoc.nii.ac.jp/jfes/ kenkyukai/abstract/B-3.pdf,2008.3.5

山下詠子（2006）入会林野における認可地縁団体制度の意義一長野県 飯山市と栄村の事例より一。林業経済 59(8)：17-32.

山下詠子（2007）混住化地域における入会集団の動態一長野県の事例 より—. http://wwwsoc.nii.ac.jp/jfes/kenkyukai/abstract/B-8.pdf, 2008.3.5

矢野達雄（2006a）入会林野の現代的再生を. 都市問題 97(11)：68.

矢野達雄 (2006b) 市町村合併と入会林野. 総合政策学科市町村合併 研究会報告書, サイト発表. http://www.cpm.ehime-u.ac.jp/research/research05_1/2-7.pdf, 2006.12.12 